\title{
Stability Performance of Some New Yellow Maize Genotypes Across Four Locations
}

\author{
Moshera S.E. Sadek, H.M. Abd El-Ghany" and M.A. Abd \\ El Moula \\ Maize Department, Field Corps Res. Inst., Agricultural \\ Research Center and *Field Corps Research Department, \\ National Research Centre Giza, Egypt.
}

\begin{abstract}
7 HIS STUDY aimed to investigate the performance and stability across four environments i.e. Gemmeiza, Sakha, Sids and Mallawy of eighteen genotypes of maize and two commercial checks hybrids (SC 155 and SC 3084). Combined analysis of variance of stability across environments indicated that significant genetic variability for all studied traits, as well as the environment indicating differential effect of each environment. Sakha location produced the highest grain yield. Most of the hybrids had a significant deviation mean square from linear regression for grain yield implying that these hybrids were unstable across environments except for seven hybrids Gm 1, Gm 2, Gm 6, Gm 9, Gm 14, Gm 17 and Gm 18 which showed small and insignificant $S^{2} d_{i}$ estimates, indicating that these hybrids could be considered to be stable hybrids. It could be concluded that the five hybrids; SC Gm 1, SC Gm 5, SC Gm 8, SC Gm 3 and SC Gm 4 can be selected since they produced the highest grain yield, and were earlier than the two check crosses. Moreover they achieved reasonable degree of stability across the four locations Gemmeiza, Sakha, Sids and Mallawy. These hybrids have to undergo progressive evaluations.
\end{abstract}

Keywords: Stability, Adaptability, Yellow Maize Environment.

In Egypt, Maize considered one of the most strategic crops either for feeding animals or human consumption. Most Egyptian cultivars have white grains; while small area is grown by yellow hybrids that their grain are used for poultry feed. To expand new yellow maize cultivars, they should characterize with high productivity and adaptability over different environmental conditions in Egypt so can be specified stable.

Maize genotypes vary in their response to variable environmental conditions. So, one of the most widely approaches in maize breeding programs is detecting the new improved hybrids for continuous and stable performance through evaluating them over these environmental conditions. Therefore, the most adapted hybrids can be identified and designate other hybrids to locations having suitable environments. Successful development of improved maize hybrids is dependent upon the accurate evaluation of genotypes performance in different locations. 
The development of genotypes varieties, and/or new hybrids which can be adapted to a wide range of diversified environments is the ultimate goal of plant breeders in a crop improvement program. Therefore, the existence of genotypeenvironment (GE) interaction requires extensive yield testing in order to identify genotypes that react less with environment. A good method to measure stability was previously proposed (Finlay \& Wilkinson, 1963) and was later improved by Eberhart \& Russel (1966) who proposed a model to test the stability of varieties under various environments. Elto \& Hallauer (1980) found that the simple correlations between mean yield and regression coefficient and mean yield and deviation from regression were highly significant.

The concept of stability has been defined in several ways and several biometrical methods including univariate and multivariate ones which have been developed to assess stability (Lin et al., 1986, Becker \& Leon, 1988 and Crossa, 1990). The most widely used one is the regression method, based on regressing the mean value of each genotype on the environmental index or marginal means of environments (Romagosa \& Fox, 1993 and Tesemma et al., 1998). Vargas et al. (1999) reported that, multi-environments trials play an important role in selection the best cultivars to be used in future years at different locations and in assessing cultivars stability across environments before its commercial release. Pixley \& Bjarnason (2002) compared the genotype $\mathrm{x}$ environment interaction and the squares of deviation from linear regression $\left(\mathrm{S}^{2} \mathrm{~d}_{\mathrm{i}}\right)$ for grain yield and arranged tested cultivars in descending manner according to their estimates single cross hybrids followed by three way, double-cross and open pollinated cultivars. Obviously the type stability related to heterogeneity level. Tollenaar \& Lee (2002) estimated stability parameters which indicated that high yielding maize hybrids can differ in yield stability but his results do not support the contention that yield stability and high grain yield are mutually exclusive. So stability parameters are useful for breeding programs.

The phenotypic performance of a genotype is not necessarily the same under diverse agro-ecological condition (Ali et al., 2003). Therefore, the adaptability of a variety over diverse environments is usually tested by the degree of its interaction with different environments under which it is planted (Arshad et al., 2003). Soliman (2006) found that, the genotypes $x$ environment interaction was highly significant for days to $50 \%$ silking and grain yield. As well as a large portion of this interaction was accounted for the linear regression on the environmental means. Plus, the magnitude of nonlinear components was considerably small. EI-Sherbieny et al. (2008) mentioned that, the high yielding potential and average stability are due mainly to the most attributes involved in determining the wide adaptation of new genotypes. Also, Abdallah et al. (2010) studied various stability parameters of the maize hybrids with respect to grain yield, days to $50 \%$ silking and plant and ear heights. Their results demonstrated that stability parameters of hybrids were different for each studied trait. 
The objective of this investigation was to identify the superior stable hybrids for number of days to $50 \%$ silking, ear position and grain yield of new promising yellow maize across four different locations in Egypt.

\section{Materials and Methods}

Eighteen yellow maize hybrids were used as new materials in this study. These genetic materials were developed at Gemmieza Agricultural Research Station, Agricultural Research Center (ARC), Egypt. These promising hybrids with two commercial yellow checks i.e., SC 155 and SC 3084 were evaluated in 2007 growing season at four locations (Gemmeiza, Sakha, Sids and Mallawy Agricultural Research Stations) in randomized complete block design with four replications in each location. Plot size was four rows, $6 \mathrm{~m}$ long and $80 \mathrm{~cm}$ apart and hills spaced $25 \mathrm{~cm}$ along the row. Two kernels were planted per hill and thinned later to one plant per hill to provide a population density of 21,000 plants/fed $\left(\right.$ feddan $\left.=4200 \mathrm{~m}^{2}\right)$. All recommended agricultural practices for maize production were applied.

At maturity, two central rows from each plot were harvested to record grain yield of each genotype. Each location was considered as an independent environment in the statistical analysis and macro-environments. The recorded data were number of days from planting to 50\% silking, ear position and grain yield (ardab / fedddan). The analysis of variance was performed according to Steel \& Torrie (1980) for each location and its combined was done after the homogeneity test (Bartlett, 1937). The hybrid effect was assumed to be fixed while the location effect was considered random. The procedures of stability analysis for these traits over locations were performed according to Eberhart \& Russell (1966). According to this model, an ideal genotype should have high mean $(X>\mu)$, a unit regression coefficient $\left(b_{i}=1\right)$ and no deviation from linearity $\left(S^{2} d_{i}=0\right)$.

The stability parameter postulated by Wricke (1962) depends on the (GE) $)_{\mathrm{lk}}$ effects, which squared and summed across all environments that was denoted as ecovalence $\left(\mathrm{W}_{\mathrm{i}}\right)$. It may be estimated as follows:

$$
\mathrm{W}_{\mathrm{i}}=\sum\left(\mathrm{X}_{\mathrm{lk}}-\mathrm{X}_{\mathrm{l} .}-\mathrm{X}_{. \mathrm{k}}+\mathrm{X} . .\right)^{2} /(\mathrm{E}-1)
$$

$\mathrm{X}_{\mathrm{lk}}=$ The interaction of genotype 1 with environment $\mathrm{k}$,

$\mathrm{X}_{\mathrm{l}}$. $=$ The genotype mean for 1 genotype across used environments,

$\mathrm{X}_{\cdot \mathrm{k}}=$ The environmental mean for $\mathrm{k}$ environment or genotypes mean in this environment

$\mathrm{X} . .=$ The general overall mean .

\section{Results and Discussion}

The pooled analysis of variance (Table 1) exposed highly significant hybrid and linear environment effect mean square for all studied traits indicating the important roles of genetic variability, and differential effect of environments. The mean square due to the linear response of hybrids to environmental indices 
was found to be significant for grain yield while non-significant for silking and ear position. On the other side, the pooled deviation mean square was highly significant for ear position and grain yield, while it was non-significant for days to $50 \%$ silking. Similar results in maize have been reported by Worku et al. (2001), El-Sherbieny et al. (2008) Mosa et al. (2011) and Abdallah et al. (2011).

TABLE 1. The joint analysis of variance for days to $50 \%$ silking, ear position and grain yield traits across four locations.

\begin{tabular}{|c|c|c|c|c|}
\hline \multirow{2}{*}{ S.O.V. } & \multirow{2}{*}{ d.f. } & \multicolumn{3}{|c|}{ Mean squares } \\
\hline & & Days to $50 \%$ silking & Ear position & Grain yield \\
\hline Hybrids $(\mathrm{H})$ & 19 & $44.14 * *$ & $65.25^{* *}$ & $80.43 * *$ \\
\hline Env, Env.V & 60 & 16.65 & $22.46^{* *}$ & $121.70 * *$ \\
\hline $\mathrm{E}$ (linear) & 1 & $784.92 * *$ & $254.31 * *$ & $5878.70 * *$ \\
\hline $\mathrm{H} \times \mathrm{E}$ (linear) & 19 & 6.00 & 8.74 & $25.29 * *$ \\
\hline Pooled Deviation & 40 & 2.37 & $23.18^{* * *}$ & $23.57 * *$ \\
\hline Gm 1 & 2 & 2.81 & 20.08 & 9.17 \\
\hline $\mathrm{Gm} 2$ & 2 & 0.42 & $35.90 *$ & 4.26 \\
\hline $\mathrm{Gm} 3$ & 2 & 2.74 & 14.62 & $16.36 * *$ \\
\hline $\mathrm{Gm} 4$ & 2 & 4.94 & 1.65 & $24.44 * *$ \\
\hline $\mathrm{Gm} 5$ & 2 & 1.57 & $31.95 *$ & $52.69 * *$ \\
\hline $\mathrm{Gm} 6$ & 2 & 8.16 & 9.23 & 1.15 \\
\hline $\mathrm{Gm} 7$ & 2 & 1.72 & 6.29 & $20.09 * *$ \\
\hline $\mathrm{Gm} 8$ & 2 & 3.93 & 7.02 & $59.83 * *$ \\
\hline Gm 9 & 2 & 2.73 & 16.78 & 2.77 \\
\hline $\mathrm{Gm} 10$ & 2 & 0.71 & 15.62 & $33.76 * *$ \\
\hline Gm 11 & 2 & 3.65 & 9.01 & $68.02 * *$ \\
\hline Gm 12 & 2 & 2.02 & 23.21 & $23.12 * *$ \\
\hline $\mathrm{Gm} 13$ & 2 & 0.94 & $59.61 * *$ & $24.17 * *$ \\
\hline $\mathrm{Gm} 14$ & 2 & 0.93 & 5.11 & 6.72 \\
\hline Gm 15 & 2 & 0.77 & 18.04 & $44.23 * *$ \\
\hline $\mathrm{Gm} 16$ & 2 & 5.38 & $90.36 * *$ & $10.74 *$ \\
\hline $\mathrm{Gm} 17$ & 2 & 1.34 & $36.75 * *$ & 2.96 \\
\hline Gm 18 & 2 & 0.10 & 0.67 & 6.37 \\
\hline SC 155 & 2 & 1.82 & $47.62 * *$ & $19.42 * *$ \\
\hline SC 3084 & 2 & 0.60 & 14.00 & $41.01 * *$ \\
\hline Pooled error & 228 & 12.98 & 7.79 & 3.11 \\
\hline
\end{tabular}

*, ** significant and highly significant at 0.05 and 0.01 probability, respectively.

The average of all studied traits at four environments in 2007 season is presented in Table 2. The results demonstrated that, Sakha location produced the highest mean value of grain yield. However, the earliest silking date was detected at Mallawy. Gemmeiza and Sids locations exhibited the lowest average of ear position character. These results indicated that, the performance of the hybrids varied from location to another.

Estimates of environmental index (Table 2) showed that Sakha location have the highest environmental index (6.29). So, Sakha location was the most favorable environment and the representative one for yield potential, contrary, Mallawy showed the lowest environmental index $(-5.81)$ so, it was the poorest yielding environment. Nevertheless, Mallawy was the most representative location for earliness. Regarding, ear position trait, the most favorable locations were Gemmeiza and Sids.

Egypt. J. Agron . 33, No.2 (2011) 
TABLE 2. Average of all studied traits and environmental index under four environments.

\begin{tabular}{|l|c|c|c|c|c|c|}
\hline \multirow{2}{*}{ Environments } & \multicolumn{2}{c|}{ Traits } & Days to 50\% silking & \multicolumn{2}{c|}{ Ear position \% } & \multicolumn{2}{c|}{ Grain yield ard/fed } \\
\cline { 2 - 7 } & Mean & $\begin{array}{c}\text { Environmental } \\
\text { index }\end{array}$ & Mean & $\begin{array}{c}\text { Environmental } \\
\text { index }\end{array}$ & Mean & $\begin{array}{c}\text { Environmental } \\
\text { index }\end{array}$ \\
\hline Gemmmeiza & 58.93 & -0.773 & 53.36 & -0.85 & 21.74 & -0.11 \\
\hline Sakha & 64.11 & 4.408 & 55.49 & 1.28 & 28.14 & 6.29 \\
\hline Sids & 59.08 & -0.623 & 53.39 & -0.82 & 21.49 & -0.36 \\
\hline Mallawy & 56.69 & -3.013 & 54.6 & 0.39 & 16.04 & -5.81 \\
\hline L.S.D. at 5\% & 1.96 & & 1.06 & & 0.67 & \\
\hline
\end{tabular}

Mean performance for the studied traits of all studied genotypes including checks across the four locations is presented in Table 3. Eight of the evaluated eighteen hybrids Viz., Gm 11, Gm 13, Gm 10, Gm 1, Gm 16, Gm 12, Gm 3 and $\mathrm{Gm} 6$ were earlier than the best check SC 155 their days to $50 \%$ to flowering were $56.63,56.81,57.25,57.50,57.69,58.25,58.75$ and 58.81 days, arranged in ascending manner and respectively. Respecting ear position, also eight hybrids among the tested hybrids had significant advantage attributed to lower ear position than the two check hybrids. These hybrids were .Gm 11, Gm 15, Gm 10, $\mathrm{Gm} \mathrm{16,} \mathrm{Gm} \mathrm{7,} \mathrm{Gm} \mathrm{12,} \mathrm{Gm} 13$ and Gm 2, in ascending arrangement. Moreover, the other ten single crosses had ear position statistically equal to the best check. The results showed that, the mean grain yield of the evaluated hybrids across four locations ranged from 26.01 ardab per feddan for SC Gm 1 to 17.44 ardab per feddan for SC Gm 9. The best single crosses for grain yield were SC Gm 1, SC Gm 5 and SC Gm 8 which significantly outweighed of the check SC 155 (22.31) and produced 26.01, 25.80 and $25.07 \mathrm{ard} / \mathrm{fed}$, respectively. It is worth to mention that, The SC Gm 1 considered the best cross which gave the highest grain yield and in the same time was early hybrid.

Stability parameters estimates for silking date, ear position and grain yield for all genotypes under study which evaluated across the four locations are presented in Table 4. According to Eberhart \& Russell (1966), the genotype with a high combined mean over a range of environments, has a regression coefficient equal to the unity $\left(b_{i}=1\right)$ and small deviation from regression $\left(S^{2} d_{i}=0\right)$ will be considered a stable genotype. Most tested hybrids showed $b_{i}$ estimates around unity therefore, these hybrids were considered stable for silking. But three hybrids (Gm 2, Gm13 and Gm 14) donated significant estimated and showed their interaction with environments. All the $\mathrm{S}^{2} \mathrm{~d}_{\mathrm{i}}$ estimates for days to $50 \%$ silking were non-significant indicating that the evaluated hybrids were stable. The ecovalence $\left(\mathrm{W}_{\mathrm{i}}\right)$ estimates calculated according to Wricke (1962) as the sum of squares of genotype environment interaction effects of a particular genotype divided by the degree of freedom (the number of environments minus 1) it can be considered as a whole estimates for stability. The estimates of $\mathrm{W}_{\mathrm{i}}$ for silking were not significant for all evaluating hybrids. 
TABLE 3. Mean performance and rank for silking date, ear position and grain yield for all maize genotypes tested under four environments.

\begin{tabular}{|l|c|c|c|c|c|c|}
\hline Traits & $\begin{array}{c}\text { Days to 50\% } \\
\text { silking }\end{array}$ & Rank & $\begin{array}{c}\text { Ear position } \\
\text { \% }\end{array}$ & Rank & $\begin{array}{c}\text { Grain yield } \\
\text { ard/fed }\end{array}$ & Rank \\
\hline Gm 1 & 57.50 & 4 & 54.75 & 12 & 26.01 & 1 \\
\hline Gm 2 & 59.06 & 12 & 53.56 & 8 & 22.10 & 11 \\
\hline Gm 3 & 58.75 & 7 & 54.25 & 9 & 23.10 & 4 \\
\hline Gm 4 & 59.19 & 13 & 54.50 & 10 & 22.77 & 5 \\
\hline Gm 5 & 59.19 & 14 & 57.56 & 20 & 25.80 & 2 \\
\hline Gm 6 & 58.81 & 8 & 57.00 & 19 & 18.46 & 19 \\
\hline Gm 7 & 59.69 & 17 & 52.88 & 5 & 22.51 & 7 \\
\hline Gm 8 & 58.88 & 10 & 55.88 & 16 & 25.07 & 3 \\
\hline Gm 9 & 58.81 & 9 & 54.63 & 11 & 17.44 & 20 \\
\hline Gm 10 & 57.25 & 3 & 51.94 & 3 & 19.61 & 17 \\
\hline Gm 11 & 56.63 & 1 & 50.06 & 1 & 22.19 & 9 \\
\hline Gm 12 & 58.25 & 6 & 52.88 & 6 & 21.33 & 14 \\
\hline Gm 13 & 56.81 & 2 & 53.00 & 7 & 22.55 & 6 \\
\hline Gm 14 & 59.50 & 16 & 54.81 & 13 & 21.98 & 12 \\
\hline Gm 15 & 59.19 & 15 & 50.63 & 2 & 19.26 & 18 \\
\hline Gm 16 & 57.69 & 5 & 52.50 & 4 & 21.81 & 13 \\
\hline Gm 17 & 60.63 & 19 & 55.63 & 15 & 20.90 & 15 \\
\hline Gm 18 & 58.94 & 11 & 55.38 & 14 & 22.16 & 10 \\
\hline SC 155 & 59.75 & 18 & 56.13 & 17 & 22.31 & 8 \\
\hline SC 3084 & 64.50 & 20 & 56.25 & 18 & 19.71 & 16 \\
\hline L.S.D at 5\% & 2.91 & & 2.24 & & 1.46 & \\
\hline
\end{tabular}

TABLE 4. Regression coefficient $\left(b_{i}\right)$, mean square deviation $\left(S^{2} d_{i}\right)$ and ecovalence (Wi) for all maize genotypes tested under four environments.

\begin{tabular}{|c|c|c|c|c|c|c|c|c|c|}
\hline Traits & Days & $50 \% \mathrm{si}$ & & & Ear positi & $n$ & Gra & n yield ar & $\mathrm{d} / \mathrm{fed}$ \\
\hline Fybrimates & $\mathbf{b}_{\mathbf{i}}$ & $\mathbf{S}^{2} \mathbf{d}_{\mathrm{i}}$ & Wi & $\mathbf{b}_{\mathbf{i}}$ & $\mathbf{S}^{2} \mathbf{d}_{\mathbf{i}}$ & Wi & $\mathbf{b}_{\mathbf{i}}$ & $\mathbf{S}^{2} \mathbf{d}_{\mathbf{i}}$ & Wi \\
\hline Gm 1 & 1.315 & 2.812 & 0.79 & 0.945 & 20.076 & 3.35 & 1.158 & 9.173 & 2.14 \\
\hline $\mathrm{Gm} 2$ & $0.333 * *$ & 0.424 & 1.53 & -0.681 & $35.895^{*}$ & 8.98 & 1.158 & 4.265 & 1.32 \\
\hline $\mathrm{Gm} 3$ & 1.195 & 2.742 & 0.58 & 0.982 & 14.618 & 2.44 & 1.021 & $16.361 * *$ & 2.74 \\
\hline $\mathrm{Gm} 4$ & 0.827 & 4.939 & 0.92 & -0.125 & 1.651 & 1.62 & 1.132 & $24.435 * *$ & 4.50 \\
\hline Gm 5 & 0.609 & 1.574 & 0.76 & 0.942 & $31.952 *$ & 5.33 & 1.034 & $52.695 * *$ & $8.81 *$ \\
\hline $\mathrm{Gm} 6$ & 1.093 & 8.160 & 1.39 & 0.058 & 9.229 & 2.48 & $0.632 *$ & 1.153 & 3.51 \\
\hline $\mathrm{Gm} 7$ & 0.498 & 1.718 & 1.11 & 1.475 & 6.292 & 1.29 & 1.212 & $20.092 * *$ & 4.45 \\
\hline $\mathrm{Gm} 8$ & 1.358 & 3.932 & 1.07 & 1.664 & 7.025 & 1.64 & 1.099 & $59.831 * *$ & $10.21 *$ \\
\hline $\mathrm{Gm} 9$ & 0.833 & 2.731 & 0.55 & 0.850 & 16.783 & 2.82 & $0.559^{*}$ & \begin{tabular}{|l|}
2.766 \\
\end{tabular} & 5.21 \\
\hline $\mathrm{Gm} 10$ & 1.135 & 0.715 & 0.18 & 1.870 & 15.623 & 3.40 & 0.207 & $33.762 * *$ & $21.01 * *$ \\
\hline Gm 11 & 1.658 & 3.653 & 2.03 & 0.112 & 9.014 & 2.34 & 0.826 & $68.024 * *$ & $12.08^{*}$ \\
\hline $\mathrm{Gm} 12$ & 1.134 & 2.021 & 0.40 & 2.545 & 23.208 & 6.40 & 0.967 & $23.125 * *$ & 3.88 \\
\hline $\mathrm{Gm} 13$ & $1.461^{*}$ & 0.941 & 0.85 & 1.451 & $59.615^{* *}$ & 10.15 & 0.750 & $24.166^{* * *}$ & 5.56 \\
\hline $\mathrm{Gm} 14$ & $1.641^{*}$ & 0.933 & 1.50 & 0.971 & 5.105 & 0.85 & 1.294 & \begin{tabular}{|l|}
6.721 \\
\end{tabular} & 3.23 \\
\hline Gm 15 & 0.725 & 0.773 & 0.38 & 1.906 & 18.037 & 3.88 & 0.886 & $44.230 * *$ & 7.69 \\
\hline Gm 16 & 1.251 & 5.380 & 1.10 & 1.041 & $90.360 * *$ & 15.06 & 1.370 & $10.742 *$ & 5.15 \\
\hline $\mathrm{Gm} 17$ & 0.630 & 1.345 & 0.67 & 0.242 & $36.752 * *$ & 6.73 & 0.906 & 2.955 & 0.71 \\
\hline Gm 18 & 0.790 & 0.101 & 0.16 & $1.848^{*}$ & \begin{tabular}{|l|}
0.671 \\
\end{tabular} & 0.87 & 1.225 & 6.375 & 2.30 \\
\hline SC 155 & 1.069 & 1.817 & 0.32 & 1.706 & $47.619 * *$ & 8.46 & 1.228 & $19.420 * *$ & 4.51 \\
\hline SC 3084 & $0.446 * *$ & 0.598 & 1.10 & 0.200 & \begin{tabular}{|l|}
13.997 \\
\end{tabular} & 3.01 & 1.334 & $41.014 * *$ & $9.57 *$ \\
\hline
\end{tabular}

$*$, ** significant and highly significant at 0.05 and 0.01 probability, respectively.

Egypt. J. Agron . 33, No.2 (2011) 
Regarding ear position, only the single cross Gm 18 showed significant $b_{i}$ value $\left(1.848^{*}\right)$ while the other hybrids ensured their stability for this trait. The estimates of $\mathrm{S}^{2} \mathrm{~d}_{\mathrm{i}}$ categorized the crosses to two groups. The first group consisted of thirteen crosses that characterized as stable, i.e., Gm1, Gm 3, Gm 4, Gm 6, Gm 7, Gm 8, Gm 9, Gm 10, Gm 11, Gm 12, Gm 14, Gm 15 and Gm 18. The second group consisted of five crosses that showed significant $S^{2} d_{i}$ estimates and characterized as unstable crosses. Respecting the $\mathrm{W}_{\mathrm{i}}$ estimates of all the crosses, all the evaluated hybrids showed non-significant estimates revealed that ear position were the more stable trait.

For grain yield, two significant estimates of regression coefficients $\left(b_{i}\right)$ were outcome for Gm 6 and Gm 9, while other tested crosses didn't differ from the unity indicating their stability. Contrary, eleven hybrids had a significant deviation mean square $S^{2} d_{i}$ from linear regression implying that these hybrids were unstable across environments, whereas seven hybrids Gm 1, Gm 2, Gm 6, $\mathrm{Gm} \mathrm{9,} \mathrm{Gm} \mathrm{14,} \mathrm{Gm} 17$ and Gm 18 showed insignificant $S^{2} d_{i}$ estimates, indicating that these hybrids proved their stability. The non-significant $\mathrm{W}_{\mathrm{i}}$ estimates that were calculated for the hybrids Gm 17, Gm 2, Gm 1, Gm 18, Gm 3, Gm 14, Gm 6, Gm 12 and Gm 4 indicated that these hybrids were stable across studied environments. In this respect Worku et al. (2001) demonstrated in general that when the adaptability parameters i.e., mean yield regression coefficient and deviation mean square from the liner regression were considered none of the genotypes exhibited general adaptability.

Finally, the results of this investigation concluded that the five hybrids Gm 1, $\mathrm{Gm} \mathrm{5,} \mathrm{Gm} \mathrm{8,} \mathrm{Gm} 3$ and Gm 4 which produced the highest grain yield, moreover, these hybrids flowered earlier than the two check crosses (SC 155 and SC 3084) and achieved reasonable degree of stability across the four locations Gemmeiza, Sakha, Sids and Mallawy. So these hybrids should be selected for advanced evaluation stages.

\section{References}

Abdallah, T.A.E., Abd El-Aal, A.M.M. and Mostfa, M.A. (2010) Stability and genotype-environment interaction for grain yield and other agronomic traits of yellow maize hybrids. Egypt. J. Agric. Res. 88, 21-32.

Abdallah, T.A.E., Abd El-Moula, A.M., El-Koomy, M.B.A., Mostfa, M.A. and Khalia, M.A.G. (2011) Genotype $x$ environment interaction and stability parameters for grain yield in some promising maize hybrids. Egypt. J. Plant Breed, 15, 61-70.

Ali, N., Javidfar, F. and Mirza,Y. (2003) Selection of stable rapeseed (Brassica napus L.) genotypes through regression analysis. Pak. J. Bot. 35, 175-183.

Arshad, M., Bakhsh, A., Haqqani, A.M. and Bashir, M. (2003) Genotype-environment interaction for grain yield in checkpea (Cicer arietinm L.). Pak. J. Bot. 35 (2), 181186. 
Bartlett, M.S. (1937) “Properties of Sufficiency and Statistical Tests”. Prod. Roy. Soc. London, Series A, 160, pp. 268-282.

Becker, H.B. and Leon, J. (1988) Stability analysis in plant breeding. Plant Breed, 101, 123.

Crossa, J. (1990) Statistical analysis of multilocation trials. Adv. Agron. 44, 55-85.

Eberhart, S. and Russell, W.A. (1966) Stability parameters for comparing varieties. Crop Sci. 6, 36-40.

El-Sherbieny, H.Y., Abdallah, T.A., EI-Khishen, A.A. and Gaber , Afaf A.I. (2008) Phenotypic stability analysis for grain yield in some yellow maize (Zea mays L.) hybrids. Egypt. J. Appl. Sci. 23 (11B): 483-490.

Elto, E.G.E. Gama and Hallauer, A.R. (1980) Stability of hybrids produced from selected and unselected lines of maize. Crop Sci. 20, 623-626.

Finlay, R.W. and Wilkinson, G.N. (1963) The analysis of adaptiveness in a breeding programme. Aust. J. Agric. Res. 14, 742.

Lin, C.S., Binus, M.R. and Lefkovitch, L.P. (1986) Stability analysis: where do we stand?, Crop Sci. 26, 894-900.

Mosa, H.E., Motawei, A.A., Abd El-Aal, A.M.M. and Abd El-Azeem, M.E.M. (2011) Yield stability of some promising maize (Zea mays L.) hybrids under varying location. J. Agric. Res. Kafer El-Sheikh Univ. 37, 99-109.

Pixley, K.V. and Bjarnason, M.S. (2002) Stability of grain yield, endosperm modification and protein quality of hybrid and open-pollinated quality protein maize (QPM) cultivars. Crop Sci. 6, 1882-1890.

Romagosa, I. and Fox, P.N. (1993) Genotype-environment interactions and adaptation. In: "Plant Breeding: Principles and Prospects" (Ed.: M.D. Hayward, N.O. Bosenmark and Romagosa) pp. 373-390. Chapman and Hall.

Soliman, M.S.M. (2006) Stability and environmental interaction of some promising yellow maize genotypes. Res. J. Agric. \& Biol. Sci. 2 (6), 249-255.

Steel, R.G.D. and Torrie, T.H. (1980) "Principles and Procedures of Statistics". Mc Graw-Hill Book Company, NY., USA.

Tesemma, T., Tsegaye, S., Belay, G., Bechere, E. and Mitiku, D. (1998) Stability of performance of tetraploid wheat landraces in Ethiopian highland. Euphtytica, 102, 301-308.

Tollenaar, M. and Lee, E.A. (2002) Yield potential, yield stability and stress tolerance in maize. Field Crops Research, 213, 161-169.

Vargas, M., Crossa, J., Eeuwijk, F.A., Ramirez, M.E. and Sayre, K. (1999) Using partial least square regression, factorial regression and AMMI models for interpreting genotype x environment interation. Crop Sci. 39, 995-967.

Egypt. J. Agron . 33, No.2 (2011) 
Worku, M., Zelleke, H., Taye, G., Tolessa, B., Wolde, L., Abera, W., Guta, A. and Tuna, H. (2001) Yield stability of maize (Zea mays L.) genotypes across locations. Seventh Eastern and Southern Africa Regional Maize Conference, $11^{\text {th }}-15^{\text {th }}$ February, 2001. pp. 139- 142.

Wricke, G. (1962) Übereine Methode Zur Erfassuag der ökolgischen sterubreite in feldversuchen. Z. Pflanzenzüchtg, 47, 92-96.

(Received 11/1/2012; accepted 27/3/2012) 


\section{سلوك الثبات الوراثى لبعض تراكيب الذرة الثامية الصفراء الجديدة في أربع مناطق أنق

\author{
مشيرة صادق الشحات صادق، حاتم محمد على عبد الغتى و مجدي احمد عبد

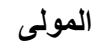 \\ قسم الذرة الثامية ـ معهد المحاصيل الحقلية ــ مركز البحوث الزر اعية و * قسم

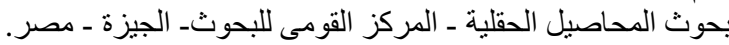

تختلف التراكيب الوراثية من الذرة الثامية فى مدى استجابتها للظروف البيائية

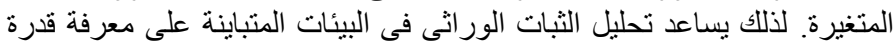

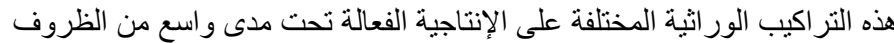

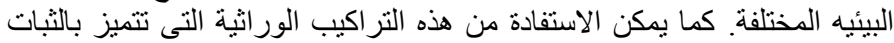

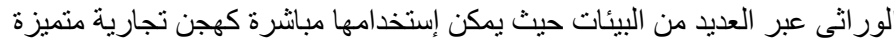

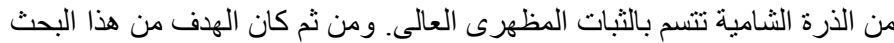

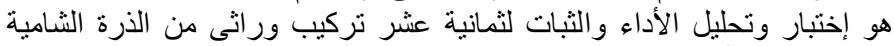

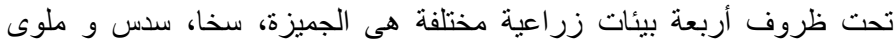

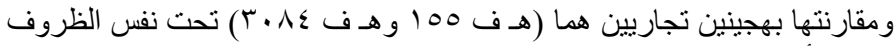

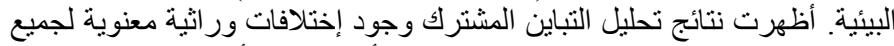

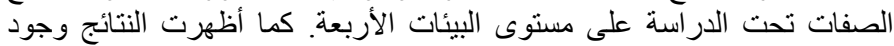

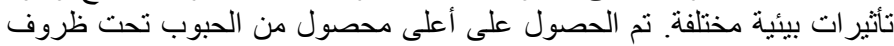

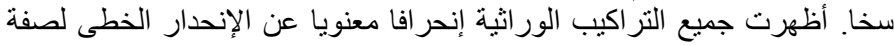

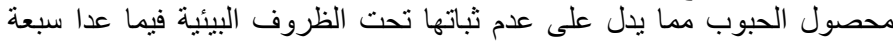

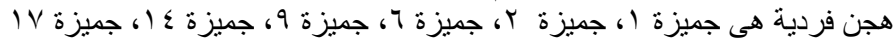

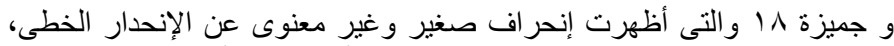

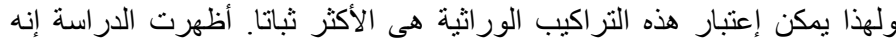

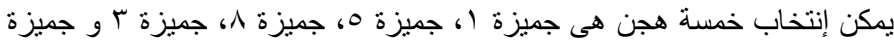

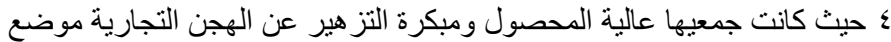

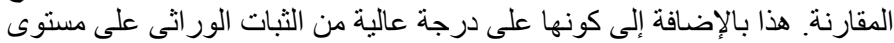

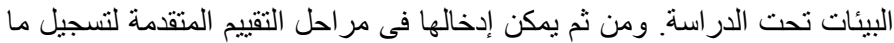

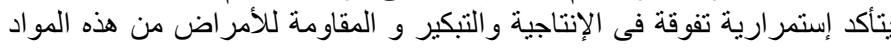

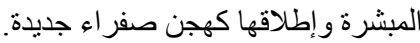

